\title{
The Empathic Myth: The War on American Indian Culture and Consciousness
}

\author{
James A. Bryant, Jr. (Hedoha Unole) \\ Appalachian State University, USA
}

\begin{abstract}
This article examines the "empathic myth:" the mythology that surrounds the American Indian and appropriates Indian consciousness and culture and twists it into a tool of oppression in modern America. The article argues that America's understanding of her Indian population has been warped by this myth and that the myth continues to perpetuate racism, ignorance and intolerance across the United States. The article offers numerous examples of this myth in practice, and concludes with a call to combat the empathic myth through activism and education.
\end{abstract}

\section{Introduction}

J. D. Meisler Middle School is duly proud of its legacy of diversity and tolerance. Located in Metarie, Louisiana on the outskirts of New Orleans, Meisler boasted in a 2002 Times-Picayune article of a student body population that numbered students from thirtyfour nationalities [1]. Entering the school lobby, a visitor is immediately confronted with the myriad of colored flags lining the walls, giving the impression that one has entered a sort of mini-United Nations right here in the nation's deep South. Native Louisiana children mix in classrooms with students from South Korea, Syria, Bosnia, and other nations scattered across the globe. An eighth grade student from Argentina named Juan Juarez bragged that he had "friends from all over the world [1]."

It was therefore quite shocking to enter this multicolored quilt of a school's office and be confronted with a cigar-store Indian. My silent prayer was that the school principal was attempting to teach students about satire or maybe hurtful stereotypes. I soon saw, however, the reason for the Indian. The school's full "name" is the J.D. Meisler Middle School Chiefs. There seemed to be no understanding of the irony that this school that was an exemplar of diversity would reduce a race of people to the role of mascot.

Dawn Mason was aware of the irony, however. Dawn moved from Minnesota to Metarie in 2001 with her son, Jack (at Dawn's request, I am not using her or her son's real name). Jack was Mandan and in the sixth grade. When Meisler celebrated "Spirit Week" during Jack's first fall there, he was thrilled at the chance to show off his Indian heritage on Heritage Day. Dawn was excited herself that morning as she watched Jack head off to school wearing his ribbon shirt. When he returned home that afternoon, though, things were far from happy. Jack darted in the door and ran crying to his bedroom. When Dawn was finally able to get him to speak to her about what had happened, he told her simply, "I don't want to be Indian anymore [2]." Dawn became irate as more and more information trickled from her devastated son.

Jack had taken a small bit of teasing because his ribbon shirt was mauve and had, of course, ribbons on it. He was called a "girl" and a "fag." But the most hurtful remarks came as a result of Jack's ethnicity. A gym teacher said to Jack, "I suppose you're trying to be an Indian [2]." A group of students cornered Jack in the hall and said, "Let's take the Indian out back and shoot him [2]." Angry and fearful for her son's safety, Dawn wrote a letter to the principal demanding a meeting.

One can imagine how daunting it must have been for Dawn as she passed the cigar store Indian on her way in to speak with the principal. She told the principal all that had transpired. She asked if, since the school had taken the name Chiefs and used an Indian image as its symbol, the student body had been educated about real Indians and real Indian issues. Dawn was given the standard canard about "honoring" Indians with the mascot. Within the year 
Dawn had pulled Jack out and placed him in another Metarie school - one without the diversity press coverage but where Jack could feel safe. He did not tell his new friends that he was Indian.

\section{Tweetsie Terrorist}

Tijuana Fats is not the most elegant restaurant in town. Surrounded by the pomp and pretense of Blowing Rock, it may, however, be one of the few places a graduate student can afford to eat in this North Carolina resort town. According to a number of online reviews, what it lacks in elegance and service it makes up for in economic friendliness. It is most certainly not a place one might expect to be threatened with execution.

Mary Rogers, a graduate student and teaching assistant in the Reich College of Education at Appalachian State University, went to Tijuana Fats that day in the summer of 2006 simply to cool off with a cold one. Mary, who is of Cherokee descent, emerged from a restroom stall and saw a "blondhaired and blue-eyed boy, probably between the ages of 3-4" staring in her direction [3]. Mary gave the boy a smile, but was met with a simmering, steely gaze in return. The boy tugged at the woman whom he was with, pointed at Mary, and asked, "Do we have to shoot her? Is she bad? [3]". The woman told the child that, no, they didn't have to shoot her, "she is good." Turning to face Mary, the woman sheepishly offered an explanation. "I'm sorry," she said, "we just spent the day at Tweetsie Railroad [3]." Stunned, Mary turned and left the restroom.

Opening to the public in the summer of 1957, Tweetsie Railroad bills itself as an Old West amusement park that provides fun for the whole family. Part of this "fun" includes white men (and, to be fair, occasionally some Cherokee Indian men from the Qualla Boundary) dressed as Plains Indians. These Indians take part in gunfights with Cowboys and, from time to time, attack the train that chugs along the amusement park tracks. Tweetsie's website promises that children visitors can help "the US Marshal fight off howling renegades." Imagine a comparable theme park that allowed children to assist in the capture of runaway slaves. The gift shop includes toy rifles, plastic "Indian" spears and tomahawks, and an Indian baby doll. As a child I visited Tweetsie with my parents, and I recall vividly the attack on the train. I also recall tearfully begging the "Indians" not to kill my Dad (my Mom is Cherokee, so I must have assumed she and I were safe). I assume this kind of thing is what Tweetsie means on its website when it says, "Mention the name 'Tweetsie' throughout the South and it conjures up memories for all age groups." To their credit, they do not promise good memories.

Mary writes:

I didn't know how to interpret the young boy's statement...part of me wondered if I was just another dark skinned dangerous person from this boy's perception after having visited Tweetsie Railroad all day. Although the mother...told the boy what is correct moral behavior, I wonder if [places] like Tweetsie Railroad perpetuate the unconscious discrimination many white people have against people of different races and ethnicities? [3]

It is, of course, impossible to know how much of this boy's hatred sprang from a day at Tweetsie. It is not too far-fetched, however, to assert that the day there contributed something to his attitude. The woman he was with certainly made that assumption. The boy's consideration of shooting Mary brings new and frightening meaning to Treatise's current PR slogan: "Tweetsie; We're a blast from the past!"

\subsection{The Spirits of Warriors are Everywhere}

A still night in Iraq or Afghanistan begins to change as the distant rumble of a helicopter is heard. The rumble soon becomes a thunderous, terrifying roar as a Blackhawk helicopter pierces the sky. From a battleship named for some famous white man, tomahawk missiles are tossed from a safe distance at unseen enemies. Paratroopers launch themselves into the black night sky. They do not cry "Sherman!" Or "Eisenhower!" Or even "Petraeus!" Their cries of "Geronimo," however, are legendary. Taha Yasin Ramadan, one of the men immortalized by the United States when his face was placed in the deck of cards depicting the most wanted Iraqi fugitives, was hunted in Iraq by "buglike OH-58 Kiowa helicopters [4]." In an insurgent attempt to assassinate Paul Wolfowitz, “...a UH-60 Black Hawk was brought down by insurgent fire [4]." Sixteen American soldiers were killed when their "CH-47 Chinook" was shot down near Baghdad. In a truly disturbing irony, a troop of the armored cavalry calls itself the Apache troop [4]. To complete the irony, these troops may be carried to or from the battlefield aboard Apache helicopters.

If the military's apparent obsession with their vanquished, one-time foe is any indication, in perhaps one hundred years paratroopers will yell "Saddam!" as they leap from planes. Sunni missiles will be fired 
from aircraft carriers. Soldiers will be ferried from the battlefield in Taliban choppers. No doubt some will see this as a tribute to a determined and deadly foe. The defeated, however, are likely to see this as simply one more insult.

\subsection{Osceola, Renegade and the Tomahawk Chop}

Historian Theda Perdue has called Osceola "the most recognizable Native American in the antebellum United States," and the famed Seminole warrior remains a popular figure into the twenty-first century [5]. Although his name would not likely spring to the lips as quickly as Sitting Bull, Geronimo or Crazy Horse might for most Americans, Osceola's name is never far from the mind of Floridians in and around Tallahassee. Osceola has gone from being a pop culture antihero in the mold of Billy the Kid during his lifetime to becoming the mascot of Florida State University. A Saint Petersburg Times article from August 2005 describes how "Chief Osceola, a student dressed in traditional clothing and wearing war paint, rides the horse Renegade into the stadium and hurls a flaming spear into the ground to excite the players and fans before football games [6]." In keeping with the spirit of the school's chosen symbol, Florida State's legendary former football coach Bobby Bowden signs autographs with the slogan, "Scalp "em." [7]. When the National Collegiate Athletic Association ruled that Indian nicknames were "hostile and abusive" and should be dropped from college teams, it was a matter so serious in Florida that it reached all the way into the governor's office. Republican Jeb Bush opened a cabinet meeting by commenting on the NCAA decision, asking, "How politically correct can we get?" and telling reporters that "the folks that [sic] make these decisions need to get out more often [8]."

It is hard to say how much the governor or Floridians in general truly know about the man they have turned into a mascot. Osceola was born in Alabama and migrated with his family to Florida during the Creek War of 1813-1814. He rose to fame during the 1830s - the decade of Andrew Jackson and Indian Removal - as a staunch fighter of removal and American attempts to force the Seminole nation to relocate to Indian Territory. Perdue writes that "Newspapers carried accounts of his exploits in the Florida swamps, and correspondents described Osceola's appearance, character, name, and facility with English [9]."
Osceola was eventually captured and held at Fort Moultrie in Charleston, South Carolina. Perdue describes the parade of authors, scholars and simple curiosity seekers who sought out an audience with Osceola during this time (including George Catlin, who "closed his New York gallery, ended his lecture series, and hurried to Charleston to paint Osceola") [9]. It was shortly after Catlin's audience and while still in captivity that Osceola died. Almost immediately, the Seminole leader's strange transformation into iconography began.

The students yelping on Saturday afternoons in Tallahassee are hardly the first to have co-opted Osceola or to have demeaned the man. The macabre story of Osceola's remains really would set the tone for the man's treatment at the hand of whites in the decades to follow. Upon his death on January 30, 1838, his physician Frederick Weedon and one of his military captors, Captain Pitcairn Morrison, seem to have drawn lots for his belongings in a scene worthy of a nineteenth century passion play. Dr. Weedon took "a carbine, powder horn, lock of hair, sketch, brass pipe, silver concho and earrings, a garter, and a knife" while Morrison absconded with "the plumes Osceola had worn in his turban, the silk shawl he used for a turban, two belts, a garter, three silver gorgets, and a mirrored hairbrush [9]."

But the most disturbing treatment of the deceased Osceola has nothing to do with the dividing up of his possessions. Before burial, Dr. Wheedon removed Osceola's head as a sort of keepsake. When he returned to Florida, Wheedon had the head with him. "According to Wheedon family tradition," Perdue writes, "he displayed the head at his drugstore or in his home for several years [9]." The final fate of Osceola's dismembered head is not known. Somewhere between the Wheedon drugstore and Doak Campbell Stadium, Osceola's humanity was lost.

His treatment was anything but exceptional, however. There have long been stories a group of pampered Yale students - including George W. Bush's grandfather Prescott Bush - stole the skull of Geronimo and that it remains hidden as part of an initiation rite for the über-elite and secretive Skull and Bones society [10]. Matthiessen recounts in his book In the Spirit of Crazy Horse the despicable treatment of the corpse of Anna Mae Pictou Aquash, "the young Micmac woman from...Nova Scotia" who was a member of the American Indian Movement [11]. Despite a documented abundance of evidence that Ms. Aquash had not died from natural causes, Dr. W.O. Brown dismissed the case as death from exposure and 
closed the case. After days in the hospital morgue, Anna Mae was buried in a local Catholic cemetery. Not, however, before Dr. Brown cut off both of her hands and shipped them off to the FBI in Washington - an odd move for a routine case of death from exposure.

When American Indian Movement members and the family of the deceased began to question the particulars of the case, the ever-compassionate Dr. Brown said, "So they found an Indian body [11]." Eventually Anna Mae was exhumed and a second autopsy was performed. The second autopsy showed that she had been murdered - "executed...at point blank range from a .38 handgun," and possibly raped [11]. Unlike Osceola's head, Anna Mae's severed hands were eventually returned to her family by FBI agent William Woods. Mattiessen's description of the scene is nauseating:

When the second autopsy was finished, the body was turned over to the Oglala people, and Bruce Ellison demanded the return of Anna Mae's hands from Agent Wood. Entirely recovered from the indignation he had displayed to Dr. Peterson [a Saint Paul pathologist who had performed Anna Mae's second autopsy] at the second autopsy, Wood grinned at him, saying, 'Oh, you want her hands?' Wood went to his car, returning with a big open-mouthed jar packed in a box. He was still grinning [11].

\section{Cultural Colonization}

\subsection{An Excessive Amount of Racial Pride}

The anecdotes recounted above tell only a tiny fraction of the story of what may well be the single most effective and devastating example of colonialism in the long, tortured history of race relations across the Earth. Volumes - not merely an article or single book - could be filled with examples of the misappropriation - the out and out theft - of the image of the American Indian. Perhaps more to the point, the very essence of what it means to be Indian has been stolen. The hijacking of all things Indian images, names, religious beliefs, ceremonies, etc. - is so ubiquitous and thoroughly pervasive throughout American culture that it now goes nearly unnoticed. Thieves are caught "red handed." Office workers are low "on the totem poll." Corporate boardrooms have "too many chiefs and not enough Indians." Angry citizens go "on the warpath."
This is not merely traditional colonialism. The issue here is more than the conquering of land and the imposition of a foreign government and value system; there is more involved than the economic exploitation of a country's natural resources and native peoples. Although all of those things exist for the indigenous population of the Americas in the twenty-first century as surely as they did in the fifteenth, this is a colonialism that is more insidious, more devastating. Indian identity itself has become a colony - controlled, manipulated, accessed and exercised by a foreign oppressor. White America has colonized the very soul of the Indian. This colonization occurred as a slow and tortuous process that evolved, morphed and grew tentacles that reached into various segments of white society and all segments of Indian culture. The result is neither syncretism nor reconciliation; it is intellectual and spiritual genocide.

Genocide is, of course, a word loaded with value and moral judgment. But Nzongola-Ntalaja reminds us that the definition of genocide in international law is "acts committed with intent to destroy, in whole or in part, a national, ethnic, racial or religious group [12]." This definition has often been interpreted to mean physical violence or oppression. But there is a recognition among social scientists that genocide may take more forms than the rifles of Sand Creek or the ovens of Auschwitz. Hamley argues that the very purpose of the Indian boarding school system of the nineteenth and twentieth centuries was "to sort, control, and mold Indian children in order to transmute their identities as members of distinct tribal cultures [13]." He goes on to remind his reader that this system of "education" was "unparalleled in United States history for what it sought to accomplish [13]." The aims, according to Hamley, were "cultural repression, indoctrination, and the use of harsh methods to achieve a dubious goal of assimilating American Indian children into the lower ranks of the American work force [13]." Or, as Adams so succinctly phrases it, the singular hope was that American Indians "would come to think like whites, and for all practical purposes, be white [14]." Lindsey writes that the purpose of Indian education was to disabuse Indian youth of "an excessive and largely unwarranted amount of racial pride [15]." 


\section{4. "To Each Age Its Own Indian"}

\subsection{Creating the Myth of the American Indian}

Zora Neale Hurston's striking description of old men gossiping on a front porch: "They passed nations through their mouths," is an accurate appraisal of what has happened to Indian identity in America [16]. America's understanding of her Indian people is more myth than reality - steeped in a romance that her pioneer forebears, greedy for land and imbued with a Manifest Destiny and firm belief that "the only good Indian is a dead Indian" would hardly have understood [17]. In his seminal work Essay on the Creative Imagination, Ribot writes that myths eventually come to be seen as "absurd, often immoral, because they are survivals of a distant epoch, cherished and consecrated through tradition, habits, and respect for antiquity [20]." Ribot sees two related components to the "psychology of the origin of the myth;" the second, and the one with which we are most interested, is "romantic invention [18]." He sees the development of and cultural attachment to myth as a necessary step in the evolution and maturation of a society. The more developed the people, Ribot argues, the less likely one will find them clinging to myths. In typical, turn-ofthe-century Eurocentric language, Ribot singles out "lower races of humanity" for approbation. But we see an almost desperate clinging to the mythical, mystical Indian white America - almost certainly a group Ribot would not classify as a lower race - has created for its own entertainment and need.

Ribot identifies two types of myth: the explicative and the non-explicative. The explicative arise "from utility, from the necessity of knowing." Where do we go when we die? What is lightening? How do we explain natural phenomena? All these are examples of questions that might give rise to explicative myths. Non-explicative myths result "from a need of luxury, from a pure desire to create." These are "epic or heroic stories, popular tales, [and] romances [18]." Yet the creation of the Myth of the American Indian does not fit well in either of these categories. Thus the Indian myth leads us to suggest a third category of myth: the empathic myth.

Remarkably, the American pattern of mythologizing her Indian population is quite predictable. First, the Indians were condemned as "savages" and "heathens" and mere obstacles in the path of America's grand fate. Then they are subjugated and placed safely away on reservations, away from their white neighbors and oppressors. A mythology grew out of this period. Dee Brown focuses on the era of 1860-1890 in his book Bury My Heart at Wounded Knee. Brown calls this time "an incredible era of violence, greed, audacity, sentimentality, undirected exuberance, and an almost reverential attitude toward the ideal of personal freedom" [19]. Brown points out that "out of that time came virtually all the great myths of the American West" and that the Indian "was the dark menace" of these myths.

The final phase of this pattern of mythologizing the American Indian is the most fascinating, though, and the most distinctly American. We live in the midst of it, and it is not at all what Ribot predicted. The mythology has not at all disappeared; rather it has taken on a new shape, a dramatic new narrative, and it fills a new need. Erna Fergusson's 1936 quip - "to each age its own Indian" - could not have been more apt [21]. The myth of the "dark savage" that was needed to rationalize the sins of the "City on a Hill" has been replaced. During the bloody years of American Empire building, the centuries when the United States expanded from sea to shining sea, a narrative was needed that would make theft, rape, murder and a national policy of genocide moral - that would convince the American people that they were still devout and still had God on their side. And as Dee Brown has shown us, the nation developed that narrative and clung to it.

\section{A Coincidence of Interests}

\section{1. "The Savage in Us"}

At some point, though, Frederick Jackson Turner declared the frontier closed. Indian wars ended. America became a continental nation. And most amazingly, though perhaps unavoidably, many white Americans began to feel a kinship with the defeated Indian peoples of the continent. The empathic myth began to take shape. As Campbell has written: "Mythology...is psychology misread as biography; history, and cosmology [22]." The psychology of the American lower and middle classes - the yeomen farmers who had been at the vanguard of the expansion - changed. What Campbell termed "the hero with a thousand faces" became the victim with a thousand faces. General John Gibbon had once remarked, "The record of white treachery and hostility would force any man to fight: thus would the savage in us come to the surface under the oppression which we know the Indian suffers [23]." 


\section{2. "Armed and Embittered Citizens"}

Many White Americans began to relate to the brutal oppression that the American Indian had faced. The mysterious maneuverings of captains of industry and the inscrutable wheeling and dealing of Wall Street came to affect the prosperity and the very survival of Main Street. Wealth came to be controlled in fewer and fewer hands. Industry took men and women out of the fields and placed them into the factory. As cities sprawled and skylines bloomed, the "way" of the Indian began to look more and more attractive. Too many men and women came to recognize that the American Dream was a reality for too few of their brethren. Writing in 1995, Martin Walker described white America - particularly white males - as "armed and embittered citizens in a state of proto-rebellion [24]." Walker lists some of the grievances of white Americans as taxation, affirmative action, abortion, and any form of gun control. The manifestation of this anger is seen in "the...intensely politicized Christian Coalition" and "self-appointed militias [24]." Suddenly, the American Indian was the perfect symbol for a million different frustrations and lost causes across this land.

Hogan, Chiricos, and Gertz describe some of the economic insecurities of Americans as the "movement of US jobs to foreign labor markets, the relentless downsizing of American corporations, [and] the transfer of productive skills to automated processes [25]." These pressures, according to their study, lead to "cultural capital that politicians and judicial actors both draw upon [25]." The authors are mostly interested in "the presumption that scapegoats are easily created in a climate of insecurity [25]." That may be so. But for our purposes the point of all this insecurity and change has led to the feeling among many Whites that they are besieged. Steinberg writes that "culture does not exist in a vacuum; nor is it fixed or unchanging. On the contrary, culture is in constant flux and is integrally a part of a larger social process [26]." In such clinical language, this notion of culture sounds almost quaint. But to the dominant society this is a terrifying and dangerous shifting of the sand. As culture changes, assumptions are challenged and dogma is shaken. The American Indian has provided white Americans with a much- needed paradigm for resistance to these culture shifts. Let Europeans turn their weathered and angry faces to Marx, America turned to Sitting Bull.

\subsection{The Empathic Myth}

Empathy is a powerful emotion. It is quite possible that empathy is the single most important factor in someday building a community of nations and a true brotherhood of man. Thus, when White America began to feel a kinship - however strained with the American Indian it had so recently vanquished - there must have been hope that a new day of racial harmony or, at a minimum justice, might be around the corner. Such was not to be the case. As white America came to feel a kinship with the American Indian, it also began to claim ownership. A new myth was written for the comfort of the dispossessed and the angry, for the disillusioned and the downtrodden. Revolutionary War veterans failed to receive promised benefits. Blue collar/white skinned American workers were gunned down in the street for attempting to organize. Hoovervilles sprang to life. World War One veterans were attacked in the nation's capitol by the very armed forces of which they had once been a part - all because they dared demand benefits they, like their Revolutionary forebears, had been promised for their service. The very foundation of Southern culture was deemed evil and ripped out by the roots. Prayer was taken out of schools. The promise of America did not seem to apply to all. Jensen writes of the fear white Americans have of "losing things we own if at some point the economic, political and social systems in which we live become more just and equitable [27]." He goes on to state that "some of what we white people have is unearned [27]." This is precisely the kind of wording that placed many whites on the defensive-whites who had struggled and suffered and worried over health care and mortgage payments didn't feel like notions of white privilege applied to them. Whites who suffered from the effects of Agent Orange and still could not get help from the Veteran's Administration didn't feel that anything had been handed to them. As anger and fear and resentment grew among a section of white America, the American Indian was an obvious symbol for their battles. A popular bumper sticker proclaims: "Sure, you can trust the government...just ask an Indian!" Empathy had arrived.

\subsection{Icon of the Angry}

The transformation from obstacle of Manifest Destiny to icon of the angry was a long one, and it began early. Brian W. Dippie cites a fascinating 
analysis by Mortin Cronin of 543 Currier and Ives lithographs that were published between 1835 and 1902. By this time, Indian Removal had been virtually accomplished, and for many Americans the Indian as a danger was fading into distant memory and the stuff of legend or pulp fiction. Dippie writes:

Of the thirty-two Indian prints, only two were meant to be funny, and neither at the expense of the Indian. "The Indian," Cronin concluded, "was recognized as a dignified human being, with a legitimate life of his own...Above all, he was taken seriously [28].

The American Indian was taken seriously because he had become fixed as an American symbol. The Indian was presented as the antithesis of the black man. As racial mores and racism in America itself evolved, the black man became the object of derision and scorn; the American Indian became the brave - though doomed object of fascination and, in many cases, awe.

The pattern was set early in the psychology of American racism. Alexis de Tocqueville had compared black and Indian by stating "The servility of one dooms him to slavery, the pride of the other to death [32]." The contrast in word choice - servility versus pride - is telling. Even the notion of slavery versus doom is important. Although the American Indian was ordained by the Christian God and America's destiny (the two of which were, of course, utterly inseparable) for extinction, the Indian nations would not go down without a fight. As Dippie writes, the Indian "was never to be sneered at." "Indians" we are told, "in contrast to blacks, were invariably described as ferociously independent and proud." One abolitionist wrote in 1861 that American blacks were despised "because he is not an insurgent [32]." The American Indian had become the ultimate symbol of a prized American character trait - resistance.

Clark Wissler wrote tellingly about the Indians' condition on their reservations after the Indian Wars had been concluded at Wounded Knee. "Naturally," he wrote, "the Indian was far from happy. I suspect that if all promises had been kept, all officials had been honest and intelligent, there would still have been sorrow and gloom because the foot of the conqueror pressed down upon the neck of the Indian [29]." Rations, medical care, promises kept - none of this would have made the Indian happy in Wissler's view. Only victory could do that; such was the character of the warrior race.

Thomas Jefferson once referred to what he saw as a coming "coincidence of interests" between white and Indian America. In Jefferson's view, these converging interests would be represented (conveniently) by the Indian's need for less and less land just as the whites needed more and more. That day never came or, perhaps more accurately, came only by brute force. But a coincidence of interests did come as large swaths of white America came to feel that their government and American culture was leaving them behind and even actively assaulting their value system or systems. What group could better represent this phenomenon than the noble Indian - vanquished but proud child of the wilderness? Thus, white America adopted the American Indian as its mascot.

\section{Reactive Movements}

\subsection{Mascot}

Malcolm X entitled a chapter of his autobiography "Mascot." He describes the psychology that exists in the behavior of the mascot and his white audience. Malcolm was a good student and a popular classmate - in short, a "model Negro." Still, he knew his "place." As he writes, “...despite all the beaming and smiling, the mascot wasn't supposed to dance with any of the white girls [30]." A terrified Chuck Berry spent the night of August 27, 1959 in the Meridian, Mississippi jail as a precaution for his own safety after the singer had allowed a young white girl to hop onto the stage and give him "... a soul-searching kiss that [he] let hang a second too long [31]." Like Malcolm, Berry could perform for the entertainment of whites, but there was a line that was crossed at his own peril.

Despite all the challenges facing Indian Country today, it is the mascot meme that seems to be most prevalent and prominent in the eyes of the national media and white America. From the Utes of the University of Utah, to the Fighting Illini of Illinois, to the Atlanta Braves, the image of American Indians is embossed across caps, jerseys and helmets from coast to coast. This is a direct result of the empathic myth and is also an issue that clearly illuminates why the empathic myth is so destructive. Communities do not name their sports franchises or local school teams for images or groups or things that seem weak or silly. These names are chosen for their symbolic strength. We call ourselves the University of North Dakota Fighting Sioux to honor the Sioux. But what if the Sioux are not honored? As Shakespeare said, there's the rub. 


\section{2. "Live Indians do not Look So Picturesque"}

Because much of white America now views itself as a besieged group, the American Indian is its symbol of resistance. Unfortunately, having taken the Indian as a symbol, the Indian has ceased to be a living, breathing group of men and women whose struggle continues. The American Indian is now frozen in amber. The Indian continues to ride horseback and fight across the plains in this white vision. Geronimo and Crazy Horse are contemporary in this vision. There is no modern American Indian. That would not be romantic. A modern Indian struggle - something like the American Indian Movement, for example would be threatening and therefore is cast aside as an anomaly not to be reckoned with. Dennis Banks, Russell Means, John Trudell, Leonard Peltier and, yes, Anna Mae Pictou Aquash, are bad Indians. Chief Joseph, Sitting Bull, Stand Watie and Attakullakulla are good Indians. It is the mythical and metaphorical equivalent to house versus field Negro. To be a good Indian, ironically, you must be dead. You must be a symbol of resistance, but your resistance must be over and you must have crossed over into the waiting arms of the Great Spirit. Nineteenth century humorist Bill Nye summed up this attitude when he wrote, "Somehow live Indians do not look so picturesque as the steel engraving does [32]." White America must be able to thoroughly co-opt you and remake you in its own image. This stereotyping is far more difficult to accomplish with live Indians demanding justice for their people.

That is precisely why the empathic myth must be recognized, called out, and demolished with the power of a modern, pan-Indian movement that refuses to be shackled to the mists of history by accepting its role as nothing more than a symbol for the oppressors' angst. George D. Spindler described what he called "reactive moments" as "those reactions to rapid change that sweep through whole populations and particularly where radically divergent cultural systems confront each other [33]." Spindler was referring to his study of the Menomini nation and their contact with and acclimation to white culture. But the notion of reactive movements also applies to many American whites and their reaction to the coming of modernity. Progress - that lovely goddess of nineteenth century America - proved herself to be a merciless mistress. In her wake came changes that left agrarian America a quaint pictograph and the promise that all men were created equal a hollow slogan too callow even to rise to the level of cherished cliché. The reactive movement white America created was one of those ironies that pepper history with color. Rather than the ultimate destruction of the American Indian that had once been openly hoped for, the government's perceived failures, the growing secularism of the nation, and a mysterious economy that seemed teeming with possibilities but paid off for an evershrinking handful meant only one thing: in the $21^{\text {st }}$ century, we are all Indians.

\section{3. "Cultural Invasion"}

But, of course, we are not all Indians. The Indian that exists through the maneuverings of the empathic myth is just that: myth. White America has created an image that is not benignly inaccurate. Rather, this myth actively perpetuates the centuries long struggle that, at its heart, gives it its very raison d'être. It would be a fascinating literary trick in a novel, but it is devastating in the geopolitical struggle for Indian survival. Though he was not speaking of American Indians, Fanon captures the essence of the empathic myth when he writes, "...the reality was not at all that of a living man, working and creating himself, but rather words, different combinations of words, and the tensions springing from the meanings contained in words [34]." Those words deserve to hang heavily in the air for a moment: the reality was not that of a living man, or a living people.

The empathic myth has been created through what Freire has dubbed "cultural invasion [35]." This is the process by which a people are allowed to exist only as fragmented, distorted images in the mirrored prism of the oppressor's experience. "In cultural invasion," Freire writes, "the actors draw the thematic content of their action from their own values and ideology; their starting point is their own world, from which they enter the world of those they invade [35]." White America views this new world order as frightening the rules have changed. Many white Americans have, therefore, developed a warped empathy with the American Indian. We are alike - they believe because we have both seen our value systems attacked. The classic American battle between civilization and savagery has changed. The modern struggle is between elites and everyone else. It is populism run dangerously amok.

Of course the kinship at the heart of the empathic myth is ridiculous. The terrible tragedy at Waco was a national disgrace to be sure - another example of government power unleashed on innocent women and 
children. But it is not Wounded Knee. The Supreme Court ruling against teacher-directed prayer is momentous, but no white child has been systematically and brutally "corrected" for praying quietly to Jesus. Catholic churches in America are never raided by the ATF for serving wine to young people under 21; but a peyote button in a Native American Church ceremony could still bring down the wrath of the law. Grammar lessons still exist in public schools - but no white child has had soap shoved into their mouths for speaking English - no matter how badly.

\section{Conclusion}

\subsection{Lost in Translation}

The empathic myth now dominates the narrative of the American Indian in our national consciousness. The Indian is romantic. The Indian is noble. The Indian is proud and resists oppression to the very death. Attacked from all sides, the Indian was defiant and a fighter. Most importantly to the success of the empathic myth, however, is the notion that the Indian is past. This narrative is central to White Americans' understanding of their own "oppression," and it is therefore to be protected. Any evidence that gets in the way of this narrative is simply discounted or ignored. It is reminiscent of the story of Sitting Bull addressing a group of whites in Philadelphia. Luther Standing Bear was a Carlisle student and in the audience that day in the fall of 1884 . He heard the Hunkpapa holy man speak on the end of the fighting between whites and Indians, and the need for the American Indian children to be educated. "I see so many white people and what they are doing," Sitting Bull said, "that it makes me glad to know that some day my children will be educated also. There is no use in fighting any longer. The buffalo are all gone... [36]". It was a forward-looking speech, but apparently not what the white audience came to hear. The white man serving as Sitting Bull's interpreter instead provided the whites with "a lurid rendition of the Little Bighorn, complete with warriors springing from ambush to wipe out all of Custer's soldiers [37]." Standing Bear ruefully wrote that the white interpreter "told so many lies that I had to smile [36]."

\section{2. "These Walking Lies"}

This tale is the perfect metaphor for the modern struggle of the American Indian. No matter the message brought by present-day American Indian activists, it is run through the prism of the empathic myth and made to suit white needs, fears and resentments. Messer-Kruse writes, "History shows that symbols can...become flash points for tensions that have accumulated throughout a society but have had no outlet for release" [38]. But what of the fact that the empathic myth does not revolve around a flag or a cross or a garish display of Ten Commandments? The empathic myth reduces the entire American Indian population to the status of symbol.

The ultimate legacy of the empathic myth is the dehumanization of the American Indian. It is the empathic myth that allows a school so self consciously proud of its diversity as Meisler Middle School to display a cigar store Indian in its office. It is the empathic myth that allows Tweetsie Railroad to view its "entertainment" as a nod to heritage and history. It is the empathic myth that allows the memory of Osceola to be desecrated on countless Saturdays in the fall in the name of entertainment. The American Indian is useful in comforting white America, in assisting white America in its quest to wrap itself in nobility, to wallow in the victory of victimhood, and to make sense of a changing and unsettling world. Indian country's very real, very modern struggle against colonialism and cultural genocide, however, does not fit into this mythological portrayal. The Indian is needed to comfort - not to challenge.

Sartre wrote of Africans taken to Europe to be "educated" in the ways of the West that, upon returning to their homeland, "These walking lies had nothing left to say to their brothers; they only echoed [39]." But the American Indian has much left to say to our brothers - American Indian brothers, white brothers, and the brothers and sisters of humanity. Sadly, the cacophony of those seeking to "honor" the Indian drowns out these messages of hope, wisdom and, yes, a demand for dignity. The misplaced empathy white America feels with the American Indian is based on the idea that American Indians have been defeated - that the struggle is over. It most emphatically is not. The American Indian desires to be a participant in America's history - not a victim. History written in a passive voice is criminal, for action defines history. The voice of the American Indian must not be allowed to be reduced to Sartre's "echo;" it must live.

Cavalry units no longer march into Indian country with guns blazing. Now it is tourists with their expectations to see feathers and powwows and to fill their lungs with the smell of sweetgrass. The 
empathic myth has made the Indian "cool." It has also, however, relegated the Indian to a sideshow, and made Indian culture a playground for white America to define itself against enemies both real and perceived. Luther Standing Bear wrote that he wrote his autobiography in order "to bring my people before [white America's] eyes in a true and authentic manner [40]." "White men who have tried to write stories about the Indian," he continued, "have either foisted on the public some blood-curdling, impossible 'thriller'; or, if they have been in sympathy with the Indian, have written from knowledge which was not accurate and reliable. No one is able to understand the Indian race like an Indian.” The empathic myth denies this fundamental truth, and in so doing it is as horrific in its effects as the bullets of Wounded Knee, and as offensive as medals of "honor" given to cold-blooded killers.

The message is simple and clear. Indian America exists - today. American Indian culture - ceremonies, matters and expressions of faith, images, and tradition - belong to the American Indian. This is not a bitter yanking away of the cultural welcome mat. White America is indeed welcome to learn American Indian ways and to study American Indian culture. Of course the wisdom of the elders will be there for the world to learn from; but it is demanded that you learn from it not appropriate it. In Land of the Spotted Eagle, Luther Standing Bear wrote, "in denying the Indian his ancestral rights and heritages the white race is but robbing itself [41]." The perpetuation of the empathic myth is an extension and continuation of this theft. It is long past time that it is stopped.

\section{References}

[1] Mark Waller, "Jeff school cherishes its unique diversity; students comes from all over", New Orleans Times-

Picayune, 15 May 2002. Retrieved August 17, 2004, from http:web.lexis-nexis.com

[2] Dawn Mason, conversation with author, New Orleans, Louisiana, 12 October 2004.

[3] Mary Rogers, email to author, 16 September 2008.

[4] Thomas Ricks, Fiasco: The American Military Adventure in Iraq (New York: Penguin), 236.

[5] Theda Perdue, "Osceola: The White Man's Indian", Florida Historical Quarterly 70(40) (1992), 475-488.
[6] Brian Landman, and Joni James, "Bush blasts NCAA as FSU plans response”, St. Petersburg Times, 10 August 2005. Retrieved August 11, 2005, from http://web.lexis-nexis.com

[7] C. Richard King and Charles Fruehling Springwood, "The Best Offense: Dissociation, Desire, and the Defense of the Florida State University Seminoles," in Team Spirits: The Native American Mascots Controversy, ed. C.R. King and C. Fruehling (Lincoln, NE: University of Nebraska Press, 2001), 129-156.

[8] Brian Landman, and Joni James, "Bush blasts NCAA as FSU plans response," St. Petersburg Times, 10 August 2005. Retrieved August 11, 2005, from http://web.lexisnexis.com.

[9] Theda Perdue, "Osceola: The White Man's Indian", Florida Historical Quarterly 70 no.40 (1992), 475-488.

[10] Stephen Singer, "Title" Sydney Morning Herald (Australia), 11 May 2006. Retrieved January 18, 2009, from http://0-www.lexisnexis.com.wncln.

[11] Peter Matthiessen, In the Spirit of Crazy Horse: The story of Leonard Peltier and the FBI's war on the American Indian Movement, (New York: Penguin, 1992), 110.

[12] Georges Nzongola-Ntalaja, The Congo: From Leopold to Kabila, A People's History (London: Zed Books, 2002), 22 .

[13] Jeffrey Louis Hamley, "Cultural Genocide in the Classroom: A History of the Federal Boarding School Movement in American Indian Education, 1875-1920" (Ph.D. diss., Harvard University, 1994), 2.

[14] David Wallace Adams, Education for Extinction: American Indians and the Boarding School Experience 1875-1928, (Lawrence, KS: University of Kansas Press, 1995), 223.

[15] Donal F. Lindsey, Indians at Hampton Institute, 18771923 (Chicago: University of Illinois Press, 1995), 111.

[16] Zora Neal Hurston, Their Eyes Were Watching God, (New York: HarperCollins, 1937), 2.

[17] Dee Brown, Bury my Heart at Wounded Knee: An Indian History of the American West (New York: Holt, 1970), 170.

[18] Th. Ribot, Essay on the Creative Imagination. (New York: Arno Press, 1906), 121.

[19] Dee Brown, Bury my Heart at Wounded Knee: An Indian History of the American West (New York: Holt, 1970), xxiii. 
[20] Th. Ribot, Essay on the Creative Imagination. (New York: Arno Press, 1906), 121.

[21] Brian W. Dippie, The Vanishing American: White Attitudes and U.S. Indian Policy, (Lawrence, KS: University of Kansas Press, 1982), 274.

[22] Joseph Campbell, The Hero With a Thousand Faces (Princeton, NJ: University of Princeton Press, 1973), 256.

[23] Sally Jenkins, The Real All Americans (New York: Broadway Books, 2007), 29.

[24] Martin Walker, “America's Angry White Males," World Press Review, 42 no.7 (1995), 28-29.

[25] Michael J. Hogan, Ted Chiricos, and Marc Gertz, "Economic Insecurity, Blame, and Punitive Ideology,"

[26] Stephen Steinberg, The Ethnic Myth: Race, Ethnicity, and Class in America (Boston: Beacon Press, 1981), ix.

[27] Robert Jensen, The Heart of Whiteness: Confronting Race, Racism, and White Privilege (San Francisco: City Lights, 2005), 53.

[28] Brian W. Dippie, The Vanishing American: White Attitudes and U.S. Indian Policy, (Lawrence, KS

[29] Clark Wissler, Red Man Reservations (New York: Collier Books, 1938), 42.

[30] Malcolm X and Alex Haley, The Autobiography of Malcolm X as Told to Alex Haley (New York: Ballantine Books, 1965), 31.

[31] Bruce Pegg, Brown Eyed Handsome Man: The Life and Hard Times of Chuck Berry (New York: Routledge, 2002), 112 .

[32] Brian W. Dippie, The Vanishing American: White Attitudes and U.S. Indian Policy (Lawrence, KS: University of Kansas Press, 1982), 134.

[33] George D. Spindler, "Psychocultural Adaptation," in The Study of Personality: An Interdisciplinary. 